\title{
A KORONAVÍRUS I. HULLÁMÁNAK HATÁSA A HAZAI DÍSZNÖVÉNYKERESKEDELEMRE A KEFAG ZRT. JUNIPERUS PARKERDÉSZET PÉLDÁJÁN KERESZTÜL
}

\section{THE IMPACT OF THE FIRST WAVE OF COVID-19 PANDEMIC ON THE DOMESTIC ORNAMENTAL PLANT TRADE BASED ON THE EXAMPLE OF JUNIPERUS}

\author{
Gmoser Dávid ${ }^{1}$, Kőszegi Irén ${ }^{2}$, Bekőné Polner Katalin ${ }^{3}$ \\ ${ }^{1}$ vidékfejlesztési agrármérnöki szakos egyetemi hallgató, Neumann János Egyetem Kertészeti és \\ Vidékfejlesztési Kar \\ 2adjunktus, Neumann János Egyetem Kertészeti és Vidékfejlesztési Kar \\ ${ }^{3}$ erdészeti igazgató, Juniperus Parkerdészet - KEFAG Zrt. \\ https://doi.org/10.47833/2021.1.AGR.006
}

\section{Kulcsszavak:}

dísznövénykereskedelem COVID-19 I. hullám hatása árbevétel alakulása Juniperus Parkerdészet

\section{Keywords:}

ornamental plant trade the first wave of COVID-19 income Juniperus

\section{Cikktörténet:}

Beérkezett 2021.február 14. Átdolgozva 2021. március 7. Elfogadva 2021. április 2.

\begin{abstract}
Összefoglalás
A világ dísznövénykereskedelmének döntő részét az Európai Unió és az USA bonyolítja le. Megfigyelhetö, hogy a dísznövénykereskedelemben egyre nagyobb szerepet töltenek be a nagykereskedelmi láncok, melyek a piac koncentrációját idézik elő. Világtendencia és az Európai Unióban is megfigyelhető, hogy a dísznövények termelési és felhasználás helyei egyre inkább elkülönülnek egymástól, a termelés zöme átkerül az afrikai és a dél-amerikai országokba, figyelemmel azok eltarthatóságára, szállithatóságára és értékére is. A faiskolai növények kereskedelme azonban továbbra is helyhez kötött egyrészt éghajlati és geológiai viszonyok, másrészt szállíthatóságuk miatt. Munkánkban a KEFAG Zrt. Juniperus Parkerdészet dísznövénykereskedelmét és az értékesítésből származó árbevételét vizsgáltuk,valamint kitértünk a 2020. évi koronavírus járvány $\mathrm{I}$. hullámának a dísznövény kereskedelemre gyakorolt hatására is.
\end{abstract}

\begin{abstract}
The bulk of the world's ornamental plant trade is handled by the European Union and the United States. It can be observed that whole salechains are playing an increasing role in the ornamental plant trade, leading to market concentration. It is a global trend and can be observed in the European Union also, that the places of production and use of ornamental plants are separated from eachother. Most of the production be transferred to African and South American countries, taking in to account the products shelf life, transportability and value. However, trade innursery plants is still place-fixed due to climatic and geological conditions on the one hand and their
\end{abstract}

\footnotetext{
* Kapcsolattartó szerző: koszegi.iren@kvk.uni-neumann.hu
} 
transportability on the other. In our work we examined the ornamental plant trade and sales revenue of Juniperus KEFAG Zrt. Inaddition, we taking into account the impact of first wave of the 2020 Covid-19 pandemic on ornamental plant trade.

\section{Bevezetés}

A vizsgált téma aktualitását az adja, hogy napjainkban a dísznövénytermesztés a mezőgazdaságon belül a kertészet dinamikusan fejlődő része. A Magyarországon termesztett dísznövények napjainkra versenyképessé váltak az Európai Unió (továbbiakban: EU) piacán és az ágazat exportbevételhez juttatja az országot. Mindemellett munka- és jövedelemszerzési lehetőséget teremt a vidéki lakosság számára [1]. A kertészeti szabadföldi kultúrák között a legnagyobb hozzáadott értéket adó fejlesztési terület a szabadföldi dísznövénytermesztés, ezen belül pedig igen jelentős a faiskolai növények aránya.

A világ dísznövénykereskedelmének döntő részét az EU és az USA bonyolítja le. Megfigyelhetö, hogy a dísznövénykereskedelemben egyre nagyobb szerepet töltenek be a nagykereskedelmi láncok, melyek a piac koncentrációját idézik elő. Világtendencia és az Európai Unióban is megfigyelhető, hogy a dísznövények termelési és felhasználás helyei egyre inkább elkülönülnek egymástól, a termelés zöme átkerül az afrikai és a dél-amerikai országokba, figyelemmel azok eltarthatóságára, szállíthatóságára és értékére is. A faiskolai növények kereskedelme azonban továbbra is helyhez kötött, egyrészt az éghajlati és geológiai viszonyok, másrészt szállíthatóságuk miatt. Munkánkban a KEFAG Zrt. Juniperus Parkerdészet dísznövénykereskedelmét és az értékesítésből származó árbevételét vizsgáltuk,valamint kitértünk a 2020. évi koronavírus járvány I. hullámának a dísznövény kereskedelmére gyakorolt hatására is.

\section{Irodalmi áttekintés}

\subsection{A dísznövényágazat nemzetközi szerepe}

Európában az 1960-as években megkezdődött a dísznövényágazat integrációja és kialakult az észak-atlanti termesztőkörzet (Németország, Oldenburg-Holstein). Hollandia szerepe egyre erősebbé vált (föleg a fizetőképes német piaci igényekre épülve) a szabadföldi termesztés éskereskedelem területén, és a gyümölcsfák mellett és helyett elötérbe került a díszfák, díszcserjék előállítása. A jelenlegi nyugat-európai termőtájak az 1980-as, 1990-es években alakultak ki. A legnagyobb központok: Németország, Hollandia, Belgium, Franciaország és Olaszország. A KGST felbomlását követően 1990 után, a hagyományos nyugat-európai termesztőkörzetek figyelme a kelet-európai országok piacai felé fordult. A változásokat elősegítették az Európai Unió alapelvei, az áru, a munkaerő és a tőke szabad áramlása [5].

A globalizáció a dísznövény ágazatra is jelentős hatást gyakorol. A nemesítés, szaporítóanyag-előállítás, dísznövény termesztés és forgalmazás terén megkerülhetetlen a nemzetközi cégek tevékenysége. Az EU-ban a dísznövény liberalizált termék, termesztése és elöállítása nemzetközileg nem szabályozott, ami biztosítja az ágazat korlátlan termelés- és piacbővítését, ugyanakkor az ágazat Uniós támogatása alacsony [2]. A nemzetközi viszonylatokban felerősödik a koncentráció, a centralizáció, az üzemek szakosodása. A multinacionális cégek és az áruházláncok szerepe nő a kereskedelemben. Hollandiában igen népszerüek az árverések is. Egyre nagyobb az átfedés a növényházi és a szabadföldi kultúrák között. Hagyományosan faiskolai vagy évelő kultúrákat nevelnek cserepes dísznövényként (pl. Aucuba, Skimmia, Campanula), Dél-Európában pedig szabadföldön nevelik meg a nálunk dézsásként használt (mediterrán vagy szubtrópusi) növényeket [5]. Magyarországról akadálytalanul kerülhetnek a belföldi dísznövénytermékek a gazdagabb nyugat-európai országokba, feltéve hogy versenyképesek, és ez fordítva is igaz. Az EU-s országokból pedig jó minőségü versenyképes dísznövények kerülnek Magyarországra még akkor is, ha egyre szigorodnak az ágazatra vonatkozó környezetvédelmi követelmények.Nemzetközi szinten az értékesítésböl származó bevételek kb. 30-40 \%-át költik marketingre. 
Az európai országok között a dísznövényágazat termelési értékét tekintve Hollandia vezető szerepet tölt be (1. táblázat).

1. táblázat: Néhány európai ország dísznövénytermelésének termelési értéke, 2014-2019 (millió

\begin{tabular}{|l|c|c|c|c|c|r|}
\hline \multicolumn{1}{|c|}{ ország } & 2014 & 2015 & 2016 & 2017 & 2018 & 2019 \\
\hline Hollandia & 6505,80 & 6577,96 & 6811,83 & 7042,53 & 7030,69 & 6866,22 \\
\hline Spanyolország & 2078,91 & 2133,40 & 2359,96 & 2595,15 & 2766,52 & 2733,33 \\
\hline Franciaország & 2852,20 & 2901,30 & 2803,40 & 2766,41 & 2766,40 & 2823,35 \\
\hline Olaszország & 2585,88 & 2487,48 & 2449,89 & 2538,16 & 2542,81 & 2792,23 \\
\hline Németország & 2308,86 & 2244,64 & 2202,13 & 2595,40 & 1942,29 & 2313,07 \\
\hline Egyesült Királyság & 1446,25 & 1582,47 & 1573,62 & 1541,33 & 1541,33 & 1493,20 \\
\hline Svájc & 585,70 & 637,58 & 620,76 & 620,30 & 625,72 & 608,13 \\
\hline Egyéb & 2341,12 & 2349,41 & 2430,90 & 2559,36 & 2656,52 & 2648,59 \\
\hline
\end{tabular}

Forrás: [5]

\subsection{Dísznövénytermesztés és kereskedelem Magyarországon}

Magyarország földrajzi elhelyezkedése miatt fontos szerepet tölt be a nemzetközi dísznövénykereskedelemben, ezen belül különösen az exportban meghatározó a szabadföldi faiskolai termékek aránya [4].

A dísznövények termékskálája igen széleskörü, melybe beletartozik a növények szabadföldi (faiskolai növények, díszfák és díszcserjék, rózsatő, évelők, virághagymák és virágmagok, vágott virágok, szárazvirágok, cserepesek, virágpalántákstb.) és növényházi (vágott virágok, díszfaiskolai szaporítóanyagok, egy- és kétnyári dísznövények palántanevelésestb.) termesztése. A dísznövényágazat a díszítésre alkalmas növények árutermelését és kereskedelmét, valamint a velük kapcsolatos szolgáltatásokat (pl.: park- és kertépítés, virágkötészetstb.) foglalja magában. $A$ dísznövények fő értékét esztétikus megjelenésük és díszítő funkciójuk jelenti. A növényválaszték koronként változó, melyet a mindenkori kultúra, az életkörülmények és a divat befolyásol. Jótékony hatást gyakorolnak az emberek mentalitására és környezetére, a klimatikus viszonyokra, illetve jól hasznosíthatók a tájrendezésbenis. Mindezek alapján elmondható, hogy a dísznövények termesztése és felhasználása manapság valós, és nem luxus szükségleteket (ahogy az a köztudatban gyakran a mai napig jellemző) elégít ki [2].

Magyarországon már a rendszerváltás előtt is fejlett technológiákat és újitásokat alkalmaztak a nagyüzemi dísznövény kertészetek, melyben szerepük volt a kiváló hazai nemesítő kertészmérnököknek és kutatóintézeteknek. A termesztők termékeik egy részét exportálták, és a dísznövények külkereskedelmét ebben az időben védővámok védték, melyek a rendszerváltással fokozatosan megszüntek, majd a termesztés volumene és a termesztőfelület folyamatosan növekedett az életszínvonal emelkedésével. A szabadföldi díszfaiskolai termesztés az 1960-as évekig föleg belföldi piaci igényeket elégített ki, a faiskolákban pedig jellemző volt a gyümölcsfák előállítása. A rendszerváltást követően a piacon egyre nagyobb mennyiségben jelentek meg az import dísznövények, ekkorra azonban a korábban alkalmazott technológiák elavulttá váltak és emiatt csökkent a hazai dísznövények nemzetközi versenyképessége. Majd az ágazat helyzete egyre inkább javult és egyre inkább jelentős szerepet játszik a vidékfejlesztésben is. Az ágazatban kiemelkedő az egységnyi területen előállított termelési érték és az egységnyi területen foglalkoztatottak száma. Napjainkra a globalizáció a dísznövények termesztését és piacát is elérte. A fontosabb hazai dísznövénytermesztő körzetek (Dél-Alföld, Budapest környéke, NyugatMagyarország, Kelet-Magyarország) az adott országrész kedvező földrajzi vagy éghajlati adottságait használják ki. Az ágazaton belül komoly hagyományokkal rendelkező szabadföldi faiskolai termesztés a föbb faiskolai termesztő körzetekben koncentrálódik: a Nyugat-Dunántúlon 
(pl.: Szombathely), illetve Kecskemét, Szeged környékén A magyar klíma szélsőségesebb, mint a nyugat-európai, de hidegebb, mint a mediterrán és a magyar díszfák, díszcserjék kiváló alkalmazkodóképességük miatt két télállósági zónával északabbra is sikeresen ültethetőek. A beruházás tőkeigénye ezen területeknek is meglehetősen magas. A befektetés után legalább 3-4 év, átlagosan 5-8 év, de bizonyos fajoknál a kívánt méret miatt 10-20 év is eltelik az árbevétel jelentkezéséig [4].

A dísznövény ágazat a mezőgazdasági ágazaton belül kis szegmenst jelent, azonban a mezőgazdasági ágazatok között jelentős termelési értéket realizál. A Központi Statisztikai Hivatal $(\mathrm{KSH})$ adatai szerint a dísznövényágazat termelési értéke 30 milliárd $\mathrm{Ft}$, a gazdasági eredménye 70-80 milliárd Ft közé tehető [5].

A hazai dísznövényágazat erősségei között említhető_a kertészeti hagyományok megléte, a magas színvonalú oktatás, szakmai felkészültség, a földrajzi elhelyezkedés, a kedvező talajviszonyok és éghajlati adottságok valamint a kiváló kapcsolatrendszerek. Gyengeségként jelentkezik: a tőkeszegénység, a technikai elmaradás, a szervezetlen termelés, a kereskedelem, és a marketing hiánya. Lehetséges kitörési pontok lehetnek: a nemesítés, az innováció, az új technológiák bevezetése, a természeti adottságok kihasználásával a versenyképesség fokozása az Európai Unión belül (pl. termálvíz, talaj adottságok), a belföldi kereskedelem fejlesztése, növelése, az exportpiacok bővítése, új felhasználási és fogyasztási területek (balkon, temető, zöldtető), a támogatások és az önfinanszírozás megfelelő arányának kialakítása és a foglalkoztatás bővítése. Veszélyként jelentkezik az import nagy mennyisége (dömping áruk) és az erős piaci verseny [2].

Az alábbiakban a magyarországi dísznövényágazat termőterületének, foglalkoztatottságának, nettó árbevételének és külkereskedelmének alakulását mutatjuk be a 2014-2019 közötti időszakban. (Az adatok többnyire becsült adatok, mivel az Agrárgazdasági Kutató Intézet által végzett Országos Statisztikai Adatgyüjtési Programban (OSAP) nem minden érintett termelő vesz részt, a dísznövényágazatban hozzávetölegesen évente körülbelül 400 adatszolgáltató ad érdemi adatokat.)

$A z$ 2. táblázat adataiból látható, hogy a dísznövénycsoportok közül a faiskolai növények termöterülete volt a legnagyobb, ami évente az összes területhasznosítás több mint $90 \%$-át jelentette. A fennmaradó kevesebb, mint $10 \%$-on vágott virág és vágott zöldtermesztés, valamint cserepes, hagymás dísznövénytermesztés folyt. A faiskolainövények termesztése szinte teljes egészében szabadföldi területen történt. $A z$ összes termőterület a hat év közepe táján kis mértékü csökkenést, majd az utolsó évben közel 200 hektár (15\%-os) növekedést mutat az első vizsgált évhez képest. Ugyancsak csökkent, majd növekedett az idöszak végére a szabadföldi (175 hektárral - 13,3 \%-kal), illetve faiskolai termékek (179 hektárral - $15 \%$-kal) köre. A kertészek, kertészetek túlnyomó többsége (42-49\%-a) fő tevékenységként faiskolai termeléssel foglalkozott.

2. táblázat: Dísznövénytermesztésre használt terület (hektár)

\begin{tabular}{|l|l|l|l|l|}
\hline \multicolumn{1}{|c|}{ év } & \multicolumn{1}{c|}{ összes terület } & \multicolumn{1}{c|}{ szabadföldi } & \multicolumn{1}{c|}{ faiskolai } & fedett \\
\hline 2014 & 1321 & 1257 & 1188 & 64 \\
\hline 2015 & 1329 & 1246 & 1235 & 83 \\
\hline 2016 & 1272 & 1209 & 1157 & 63 \\
\hline 2017 & 1280 & 1214 & 1145 & 66 \\
\hline 2018 & 1521 & 1441 & 1323 & 67 \\
\hline 2019 & 1518 & 1432 & 1367 & 70 \\
\hline
\end{tabular}

Forrás: [5]

A disznövényágazat jellemző gazdálkodási formája a mikro- és kisvállalkozás, illetve a családi gazdaság. A kertészetek számottevő része vidéken található, ahol fontos szerepet tölthetnek be a helyi lakosok foglalkoztatásában. A foglalkoztatottsági adatok a vizsgált hat évben nagyjából azonos szinten voltak, az utolsó két évben a foglalkoztatottak száma hozzávetőlegesen a kezdő év egynegyedével, 510-531 fővel (25 \%-kal) emelkedett. Megfigyelhetö, hogy évről-évre nagyobb a 
teljes munkaidőben való foglalkoztatás, ami hozzájárult az ágazat stabilitásához, az ilyen módon foglalkoztatottak száma hat év alatt kb. 12,5 \%-kal nőtt, míg a részmunkaidősök száma közel a felére csökkent. Nagyobb arányban, több mint két és félszeresével nőtt az alkalmi munkát vállalók száma, ami az ágazat idény jellegével is összefügg, a kertészetek nagy számban foglalkoztatnak betanított szezonális munkaerőt. E munkavállalókon kívül sok segítő családtag is részt vett a termelésben, azonban ezek számáról nem minden évben állt rendelkezésre adat. A faiskolákban, a dolgozók száma hektáronként átlagosan 1 fö, míg az intenzívebb növénykultúráknál $6-10$ fö között mozgott (3. táblázat).

3. táblázat: Foglalkoztatottsági adatok a dísznövénytermesztésben (fö)

\begin{tabular}{|l|l|l|l|l|}
\hline év & \multicolumn{1}{|c|}{$\begin{array}{c}\text { összes } \\
\text { foglalkoztatott }\end{array}$} & \multicolumn{1}{|c|}{$\begin{array}{c}\text { teljes } \\
\text { munkaidös }\end{array}$} & $\begin{array}{c}\text { rész- } \\
\text { munkaidős }\end{array}$ & $\begin{array}{c}\text { alkalmi } \\
\text { munkavállaló }\end{array}$ \\
\hline 2014 & kb. 2000 & 1260 & 400 & kb. 300 \\
\hline 2015 & kb. 2100 & 1340 & 351 & kb. 400 \\
\hline 2016 & kb. 2000 & 1189 & 282 & kb. 500 \\
\hline 2017 & 1965 & 1205 & 244 & kb. 500 \\
\hline 2018 & 2531 & 1409 & 261 & kb. 800 \\
\hline 2019 & 2510 & 1419 & 234 & kb. 850 \\
\hline
\end{tabular}

Forrás: [5]

A vizsgált hat évben a dísznövénykategóriák közül a faiskolai tevékenység nettó árbevétele volt a legmagasabb, míg a vágott virág és vágott zöld termékeké a legalacsonyabb. A cserepes, hagymás növények nettó árbevétele nagyjából azonos szinten mozgott, az utolsó évben közel harmadával nőtt. Az egy hektárra vetített legmagasabb nettó árbevételt a cserepes, hagymás növények termesztése érte el (4. táblázat).

4. táblázat: Értékesités - a dísznövénytermesztés nettó árbevétele (a megszerzett és realizált bevételek értéke, a teljesitett termékértékesitések, szolgáltatások áfa nélküli ellenértéke)

\begin{tabular}{|c|c|c|c|c|c|c|c|}
\hline év & $\begin{array}{c}\text { dísz- } \\
\text { növény } \\
\text { ágazat } \\
\text { (milliárd } \\
\text { HUF) }\end{array}$ & $\begin{array}{l}\text { vágott } \\
\text { virágok, } \\
\text { vágott } \\
\text { zöld } \\
\text { termé- } \\
\text { kek } \\
\text { (milliárdH } \\
\text { UF) }\end{array}$ & $\begin{array}{l}\text { cserepes, } \\
\text { hagymás } \\
\text { stb. növé- } \\
\text { nyek } \\
\text { (milliárdH } \\
\text { UF) }\end{array}$ & $\begin{array}{c}\text { faiskolai } \\
\text { termé- } \\
\text { kek } \\
\text { (milliárdH } \\
\text { UF) }\end{array}$ & $\begin{array}{c}1 \text { hektárra } \\
\text { jutó } \\
\text { faiskolai } \\
\text { termékek } \\
\text { (millióHUF) }\end{array}$ & $\begin{array}{l}1 \text { hektárra } \\
\text { jutó } \\
\text { cserepes-, } \\
\text { balkon-, } \\
\text { hagymás } \\
\text { növények( } \\
\text { millióHUF) }\end{array}$ & $\begin{array}{c}1 \\
\text { hektárra } \\
\text { jutó } \\
\text { vágott virág } \\
\text { (millióHUF) }\end{array}$ \\
\hline 2014 & 8,7 & 2 & 2,3 & 4,4 & 3,8 & 63 & 21,1 \\
\hline 2015 & 9,1 & 1,5 & 2,4 & 5,2 & 4,2 & 53,4 & 30 \\
\hline 2016 & 8,8 & 1,5 & 2,5 & 4,8 & 4,1 & 66,2 & 34,2 \\
\hline 2017 & 10,2 & 1,7 & 2,9 & 5,6 & 4,9 & 69,6 & 34,1 \\
\hline 2018 & 11,7 & 2 & 2,9 & 6,4 & 4,8 & 61,7 & 33 \\
\hline 2019 & 12,5 & 1,6 & 3,4 & 7,5 & 5,5 & 79 & 18,3 \\
\hline
\end{tabular}

Forrás: [5]

Az exportban meghatározó a faiskolai termékek aránya (5. táblázat). A vágott virágok importja jelentősen meghaladta az évröl-évre csökkenő exportértékét, és külkereskedelmi egyenlege fokozatosan romlott, az első évhez képest több mint felével csökkent az export, az import évente nagyjából azonos mértéket mutatott. A faiskolai termékcsoport import értéke a bázis évhez képest 
több mint duplájára, exportja pedig egyharmadával növekedett és pozitív külkereskedelmi egyenleget mutatott. Dísznövény exportunk döntő többsége a környező országokba (föleg Romániába, Szlovákiába) és a német piacra került. Az import áru túlnyomórészt Hollandiából, Németországból és Olaszországból érkezett.

5. táblázat: Dísznövény külkereskedelem értéke (millió forint)

\begin{tabular}{|c|c|c|c|c|}
\hline \multirow[t]{2}{*}{ év } & \multicolumn{2}{|c|}{ friss vágott virágok } & \multicolumn{2}{|c|}{ faiskolai termékek (fa, bokor, cserje) } \\
\hline & export & import & export & import \\
\hline 2014 & 1200 & 4500 & 1700 & 1000 \\
\hline 2015 & 1300 & 4700 & 1300 & 1000 \\
\hline 2016 & 535 & 4700 & 965 & 964 \\
\hline 2017 & 856 & 5100 & 2133 & 1915 \\
\hline 2018 & 708 & 4100 & 2140 & 1969 \\
\hline 2019 & 526 & 4600 & 2276 & 2579 \\
\hline
\end{tabular}

Forrás: [5]

A vizsgált hatéves időszakról a négy táblázat becsült adatai alapján megállapítható, hogy a dísznövényágazat termőterülete $(13 \%-k a l)$, a foglalkoztatottak száma (25\%-kal) és nettó árbevétele (43\%-kal) növekedett, míg a dísznövény termékek export-import egyenlege évröl-évre negatív volt. Magyarország nettó importőr, és az importérték aránya kb. $60 \%$ körüli. A legdinamikusabban fejlődő faiskolai termékcsoport termőterülete $15 \%$-kal, nettó árbevétele 70 \%kal, az export értéke 34\%-kal növekedett pozitív külkereskedelmi egyenleg mellett. A területnövekedés és a nettó árbevétel növekedési ütemének egymáshoz való viszonya alapján megállapítható, hogy a faiskolai termelők fajlagosan nagy értéket állítanak elő.

\section{Anyag és módszer}

A Juniperus Parkerdészet az állami tulajdonú, kecskeméti székhelyű KEFAG Kiskunsági Erdészeti és Faipari Zrt. jogelödje hozta létre 1991-ben a dísznövénytermesztés dél-alföldi termesztőkörzetében (1. ábra). A termesztőkörzet sajátosságai a Juniperusnál is megfigyelhetök, mint például a napsütéses órák magas száma, az egyre kiszámíthatatlanabb csapadékmennyiség, a kedvezőtlen talajadottság (homokos talaj - futóhomok), a területek alacsony átlagos aranykorona értéke (3,33 AK/ha). A kedvezőtlen adottságú talaj- és klimatikus viszonyok ellenére mégis az itt megtermelt dísznövények az értékesítést követően életképesek maradnak szélsőséges környezeti körülmények mellett is.

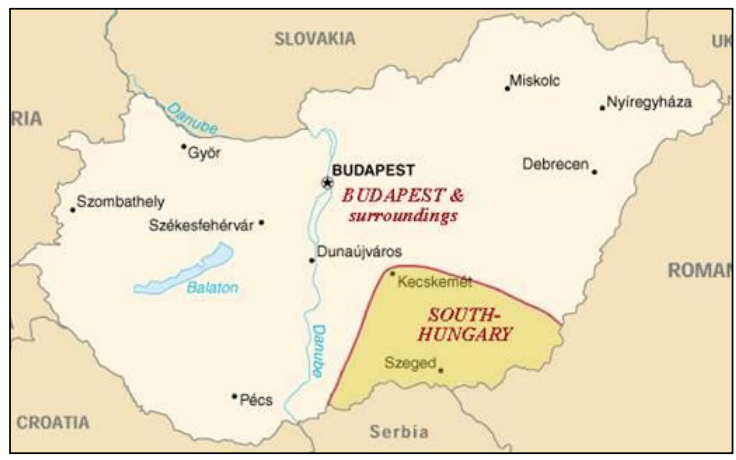

1. ábra: Dél-alföldi termesztökörzet

Forrás: [2] 
A cég fö tevékenysége a dísznövénytermelés és értékesítés, valamint a dísznövény kereskedelem. A termékkörbe elsősorban díszfák, örökzöldek, díszcserjék, másodsorban kerti kiegészítők, kaspók, virágföldek és egyéb kertészeti kellékek tartoznak. A dísznövényekkel nem csak kereskedik, hanem azok továbbnevelésében is részt vesz pl: szabadgyökerű fák konténeres nevelése, örökzöldek földlabdázása, kis cserepes és tálcás cserjék nevelése 2-3 literes konténerben. A társaság összességében mintegy 60 hektár nagyságú területen folytat növénytermesztö tevékenységet. Ebböl 40 hektár a központi kecskeméti telephelyen, 20 hektár az ország nyugati részén, Szombathelyen található. Utóbbi helyszínen a földlabdás örökzöldek és fák nevelése zajlik. A termékskála folyamatos bővítése céljából a cég kapcsolatot tart a termékkört előállító termelőkkel és együttműködik kutatóintézetekkel is.

A Juniperus kis- és nagykereskedelmi kapcsolatai nemcsak a kiskunsági régiót, hanem az ország egész területét lefedik, sőt nemzetközi - elsősorban a környező országokkal kiépített kapcsolatokkal is rendelkezik. A kiskereskedelem elsősorban az edzett, szélsőséges körülményeket is jól türő díszfákra, cserjékre, többször iskolázott fákra, gyümölcsfákra, örökzöldekre és szoliter növényekre koncentrálódik a cég árudájában. A nagykereskedelem a kertés parképítők, önkormányzatok és intézményeik, beruházó cégek, viszonteladók kiszolgálására épül fel. Az importkereskedelem a nagy kertészeti hagyományokkal rendelkező országokkal (Hollandia, Olaszország), az exportkereskedelem pedig a dél-alföldi dísznövénytermesztő körzet szomszédos országaival (pl: Románia) zajlik. A Juniperus tevékenysége kiegészül marketing tevékenységgel is, mely az elmúlt évek tapasztalatai, forgalmi adatai alapján szezonálisan kerül kialakításra.

\section{Eredmények}

\subsection{A Juniperus árbevételének és az értékesített növények számának alakulása 2015-től 2020-ig}

Táblázatok segítségével bemutatjuk a Juniperus nettó árbevételének (6. táblázat), árbevétel változásának (7. táblázat), a belföldi és export értékesítés arányának (8. táblázat) alakulását, valamint az értékesített növények darabszámát (9.táblázat) 2015 és 2020 között. (Megjegyzés: a táblázatokban a 2020-as év január 1-től október 31-ig terjedő, 10 havi időszak adatait tartalmazza.) A vizsgált időszakban a nettó árbevétel 2018-ig a 2015 évihez képest csökkenő tendenciát mutat a kedvezőtlen, szélsőséges tavaszi időjárás miatt. A legnagyobb visszaesés 2016-ban következett be. Ez az év a teljes dísznövényágazat nettó árbevételének legnagyobb arányú csökkenését mutatja (6-7. táblázat). A 2019. év már minden szempontból optimális volt, rekord árbevételt keletkezett az előző évihez képest, a növekedés kb. $140 \%$ volt (108 $039331 \mathrm{HUF}$ ), és mintegy 86 millió forinttal haladta meg a 2015. évi bevételt. A 2020. év eddigi összes árbevétele 105,72 \%-kal haladja meg az előző évi 10 havi nettó árbevételt, a belföldi árbevétel kb. azonos az előző évi időarányos bevétellel (100,43 \%), az export pedig 112,53 \%-kal haladja meg azt. Ezek az adatok alátámasztják azt a tényt, hogy a 2020. évi koronavírus-járvány nem idézte elő a Juniperus tervezett árbevételének csökkenését. 
6. táblázat: A Juniperus éves nettó árbevétele 2015-2020 években

\begin{tabular}{|l|l|l|l|}
\hline$E ́ v$ & Belföldi árbevétel (HUF) & Export árbevétel (HUF) & Összes árbevétel (HUF) \\
\hline 2015 & 173201706 & 125404098 & 298605804 \\
\hline 2016 & 164277549 & 112489962 & 276767511 \\
\hline 2017 & 174718555 & 107678255 & 282396810 \\
\hline 2018 & 148833701 & 127714023 & 276547724 \\
\hline 2019 & 228805722 & 155781333 & 384587055 \\
\hline $2020^{*}$ & 183747886 & 128391075 & 312138961 \\
\hline
\end{tabular}

Megjegyzés: * a 2020-as év január 1-töl október 31-ig terjedő, 10 havi időszak adatait tartalmazza

Forrás: Juniperus adatai alapján saját szerkesztés

7. táblázat: Árbevétel változások az előző évhez viszonyítva 2015-2020 években

\begin{tabular}{|l|l|l|l|l|l|l|}
\hline \multirow{2}{*}{$E ́ v$} & \multicolumn{2}{|c|}{ Belföldi } & \multicolumn{2}{c|}{ Export } & \multicolumn{2}{c|}{ Összes } \\
\cline { 2 - 7 } & \multicolumn{1}{|c|}{ HUF } & \multicolumn{1}{c|}{$\%$} & \multicolumn{1}{c|}{ HUF } & \multicolumn{1}{c|}{$\%$} & \multicolumn{1}{c|}{ HUF } & \multicolumn{1}{c|}{$\%$} \\
\hline 2015 & 36742848 & 160,93 & 41308523 & 149,12 & 78051371 & 135,39 \\
\hline 2016 & -8924157 & 95,07 & -12914136 & 89,70 & -21838293 & 92,69 \\
\hline 2017 & 10441006 & 112,60 & -4811707 & 95,72 & 5629299 & 102,03 \\
\hline 2018 & -25884854 & 84,59 & 20035768 & 118,61 & -5849086 & 97,93 \\
\hline 2019 & 79972021 & 158,05 & 28067310 & 121,98 & 108039331 & 139,07 \\
\hline $2020^{*}$ & 2590987 & 100,43 & 14301069 & 112,53 & 16892056 & 105,72 \\
\hline
\end{tabular}

Megjegyzés: * a 2020-as év január 1-töl október 31-ig terjedő, 10 havi időszak adatait tartalmazza

Forrás: Juniperus adatai alapján saját szerkesztés

Az összes árbevételen belül a belföldi értékesítés mindig meghaladta az exportot (8. táblázat), átlagosan 60 - $40 \%$ az arányszámuk, ez alól kivétel a 2018. év, amikor az exportértékesítés a legmagasabb volt (46\%) a vizsgált időszakban.

A 2020. év eddigi arányai: a belföldi árbevétel kb. kétharmad részt, az export árbevétel $\mathrm{kb}$. egyharmad részt képvisel a teljes nettó árbevételből.

8. táblázat: A belföldi és az export értékesités százalékos aránya 2015-2020 években

\begin{tabular}{|l|l|l|}
\hline \multicolumn{1}{|c|}{$\dot{E} V$} & \multicolumn{1}{|c|}{ Belföldi (\%) } & Export (\%) \\
\hline 2015 & 58 & 42 \\
\hline 2016 & 59 & 41 \\
\hline 2017 & 61 & 39 \\
\hline 2018 & 54 & 46 \\
\hline 2019 & 59 & 41 \\
\hline $2020^{*}$ & 69 & 31 \\
\hline
\end{tabular}

Megjegyzés: * a 2020-as év január 1-töl október 31-ig terjedő, 10 havi időszak adatait tartalmazza

Forrás: Juniperus adatai alapján saját szerkesztés

Az értékesített növények darabszáma csökkenést mutat, ami még 2019-ben sem érte el a 2015. évi mennyiséget, azonban a nettó árbevétel a csökkenő darabszám ellenére 2019-re mégis növekedett (9. táblázat). Ez az ellentétes trend azzal magyarázható, hogy az eladott növények egyre magasabb minőséget képviselnek és egyre értékesebbek, így kevesebb darabszámú 
értékesítéssel is el lehetett érni a magasabb árbevételt. Ennek oka az is, hogy az utóbbi években a magasabb értékủ díszfák, örökzöldek forgalma meghaladta a kisebb értékủ cserjék forgalmát mind az export, mind a hazai dísznövények tekintetében, továbbá az egyes dísznövények ára általában 10 \%-kal emelkedik évröl-évre, növénycsoportoktól függően.

9. táblázat: A Juniperus által értékesittett növények 2015-2020 években

\begin{tabular}{|l|l|l|l|}
\hline \multicolumn{1}{|c|}{ Év } & \multicolumn{1}{|c|}{$\begin{array}{c}\text { Belföldi } \\
(d b)\end{array}$} & \multicolumn{1}{|c|}{$\begin{array}{c}\text { Export } \\
(d b)\end{array}$} & \multicolumn{1}{c|}{$\begin{array}{c}\text { Összes } \\
(d b)\end{array}$} \\
\hline 2015 & 279295 & 121965 & 401260 \\
\hline 2016 & 244053 & 109495 & 353548 \\
\hline 2017 & 196680 & 77168 & 273848 \\
\hline 2018 & 151419 & 78181 & 229600 \\
\hline 2019 & 219775 & 90661 & 310436 \\
\hline $2020^{*}$ & 134149 & 59853 & 194002 \\
\hline
\end{tabular}

Megjegyzés: * a 2020-as év január 1-töl október 31-ig terjedő, 10 havi időszak adatait tartalmazza

Forrás: Juniperus adatai alapján saját szerkesztés

\subsection{A koronavírus járvány első hullámának hatása a Juniperus Parkerdészetnél}

A koronavírus járvány első hulláma miatti veszélyhelyzet által a mezőgazdaság legsúlyosabban érintett ágazata 2020. tavaszán a dísznövényágazat volt. Ezt tovább tetőzte a 2020 tavaszi szélsőséges időjárás is (20 fokos hőmérséklet, majd utána fagyok). A tavaszi főszezonban a nyitvatartási korlátozások és a csökkenő kereslet miatt a termékek jelentős része tönkrement és a dísznövénytermelők- és kereskedők a tervezett éves árbevétel jelentős részétől estek el, melyek kiesése később már nem pótolható. A Díszkertészek Szakmaközi Szervezetének becslése szerint a koronavírus-járvány első hulláma kb. 174 milliárd forint veszteséget okozhat a dísznövényágazat szereplöi számára, ami a tervezett bevételek közel $70 \%$-át is jelenheti. A tavaszi veszélyhelyzet rendkívül kedvezőtlenül érintette az egynyári-, a balkonnövény-, a vágott virág- és a díszfaiskolai termesztők körét, valamint a kertészeti árudákat és a virágkereskedőket, akik teljes tökéjüket is elveszthetik. A vágottvirág-termesztők a bevételkiesést a tervezetthez képest $85 \%$-ra, az egynyári-, és balkonnövény termesztők $80 \%$-ra, a díszfaiskolai termesztők $50 \%$ körülire becsülik. A hazai termelés és kereskedelem gyengülése a külföldi áruk beözönlését is eredményezheti akkor is, ha a legtöbb faiskolai termék és egynyári növény eddig a hazai termelőktől magyar munkaerő által kerül a piacra.

Az agrárminiszter és a NÉBIH szolidaritásból arra hívta fel a dísznövényt vásárolni szándékozók figyelmét, hogy hazai dísznövénytermékeket vásároljanak hazai kertészetekböl és árudákból. A dísznövénykertészek nyílt levelekben arra kérték vásárlóikat, többek között az önkormányzatokat is, hogy ne mondják vissza megrendeléseiket. A kezdeti pánikhangulatban azonban az áruházláncok megrendeléseiket visszamondták, majd amint újra kinyithattak, elkezdtek rohamtempóban rendelni. Ez is mutatja annak a laza szerződéses rendszernek a hibáit, miszerint a nagyobb kereskedők jellemzően elörendelést adnak le, ami nem jelent részükröl fizetési kötelezettséget, ha azonban a termelő nem tudja teljesíteni a vállalt mennyiséget, úgy azonnal kötbérrel sújtják. 2020 májusában már a legtöbb kereskedőnek az volt a kihívás, hogyan tudják kielégíteni a hirtelen visszaálló keresletet. A zöldfelület gazdálkodást kevésbé érintette hátrányosan a járványhelyzet, ugyanis az építőipari dísznövény megrendelések folyamatosak voltak.

A járványhelyzet a munkaerőpiaci helyzetet átmenetileg enyhítette, hiszen más ágazatokból elérhetővé váltak dolgozók. Az ágazat a korábbi években nem volt támogatott, azonban a kormány a Gazdaságvédelmi Akcióterv részeként a veszteségek mérséklése céljából a dísznövényágazat szereplöit is átmeneti támogatásban részesítette. A dísznövénytermesztők részére összesen 1,4 
milliárd forint kormányzati támogatást nyújtottak. Járulékkedvezményként a dísznövénykertészetek pályázat alapján foglalkoztatottanként ötszázezer forint vissza nem térítendő támogatást kaptak. A járulékkedvezményen felül a többi gazdasági szereplöhöz hasonlóan az ágazati vállalkozások is igénybe vehetik a hiteltörlesztési moratóriumot és a kisadózók adókedvezményét is. Az átmeneti támogatások 2020. nyár végére már javították az ágazati vállalkozások gazdasági helyzetét. $A$ járvány negatív hatásait - az ágazat importfüggősége, tökehiányossága okán - ellensúlyozhatná még több intézkedés is.

A Juniperusnál a tavaszi járványhelyzet nem járt a munkavállalók elbocsátásával vagy munkaidő csökkentésével. A kezdeti időszakban - 2020 márciusában - az adminisztratív dolgozók néhány napig „homeoffice”-ban dolgoztak, míg a kertészeti és faiskolai dolgozók továbbra is ellátták változatlanul munkájukat a szükséges óvintézkedések mellett. A megrendelések száma a járványidőszak kezdetén - kb. két hétig - meredeken zuhant, majd újra felívelő tendenciát mutatott. Áprilistól októberig az export és a belföldi kereskedelem az évi átlagos szintet meghaladta, ami magyarázható azzal, hogy tavasszal a járványügyi korlátozások (pl. kijárási korlátozás) miatt az emberek többsége szabadidejében otthonában kertészkedett. Ez a tendencia a nagykereskedelmi partnerekre is jellemző volt, amelyek a kertészeti munkákat a szabadban kisebb csoportokban végezték. A külföldi nagykereskedők az értékesítési láncban személyesen nem tudtak részt venni a határzár miatt, ők telefonos, illetve online kapcsolatfelvételt követően csupán fuvarozóikat küldték az áruért. Az import beszerzés egy része még év elején akadálytalanul megtörtént, majd 2020. márciustól kb. egy hónapig nem vállalkozott egy fuvarozó sem az Olaszországból történő áruszállításra. A rendszeres beszállítások április végétől indultak. A járvány okozta kedvezőtlen hatások ellenére a 2020-as év eddig eltelt időszakában a Juniperus tényadatai a tervekkel időarányosan összhangban alakultak. Mivel a társaságnál a járvány nem okozott válsághelyzetet, ezért nem volt szükség állami támogatás igénybevételére.

\section{Következtetések, javaslatok}

Táblázatok segítségével bemutattuk a Juniperus nettó árbevételének, árbevétel változásának, a belföldi és export értékesítés arányának alakulását, valamint az értékesített növények darabszámát 2015 és 2020 között. A vizsgált időszakban a nettó árbevétel 2018-ig a 2015 évihez képest csökkenő tendenciát mutat a kedvezőtlen, szélsőséges tavaszi időjárás miatt. A legnagyobb visszaesés 2016-ban következett be. Ez az év a teljes dísznövényágazat nettó árbevételének legnagyobb arányú csökkenését mutatta. A 2019. év már minden szempontból optimális volt, rekord árbevételt keletkezett az előző évihez képest, a növekedés kb. $140 \%$ volt (108 039331 HUF), és mintegy 86 millió forinttal haladta meg a 2015. évi bevételt. A 2020. év eddigi összes árbevétele 105,72 \%-kal haladja meg az előző évi 10 havi nettó árbevételt, a belföldi árbevétel kb. azonos az előző évi időarányos bevétellel (100,43 \%), az export pedig 112,53 \%-kal haladja meg azt. Ezek az adatok alátámasztják azt a tényt, hogy a 2020. évi koronavírus-járvány eddigi I. hulláma nem idézte elő a Juniperus tervezett árbevételének csökkenését.

\section{Köszönetnyilvánítás}

Köszönettel tartozunk a kutatás támogatásáért, amely az EFOP-3.6.1-16-2016-00006 „A kutatási potenciál fejlesztése és bővítése a Neumann János Egyetemen" pályázat keretében valósult meg. A projekt a Magyar Állam és az Európai Unió támogatásával, az Európai Szociális Alap társfinanszírozásával, a Széchenyi 2020 program keretében valósul meg.

\section{Irodalomjegyzék}

[1] Dísznövényszövetség és Terméktanács Elnöksége (szerk.):

A dísznövénytermesztő ágazat rövid és-hosszútávú fejlesztési tervei, az NFT 2007-13 ágazatfejlesztési koncepció keretein belül

http://www.fakertesz.hu/dokumentumok//38nftll.doc 
[2] Honfi P. - Tilliné Mándi A. (szerk.) (2011):

Korszerü kertészet Modern dísznövénytermesztés és -kereskedelem

https://regi.tankonyvtar.hu/hu/tartalom/tamop412A/2011-0028_modern_disznovenytermesztes/adatok.html

[3] Jámbor A. - Török Á. (2020): Tanulmány a Magyar Díszkertészek Szakmaközi Szervezete részére - A magyar dísznövény ágazat helyzete és kilátásai Budapest, 2020. június https://www.diszkerteszek.hu/szakmai-anyagok/

[4] Jankuné Kürthy Gy. - Kozák A. - Radóczné Kocsis T. (2010): A magyar dísznövény ágazat helyzete és kilátásai http://repo.aki.gov.hu/307/1/ak_2010_04.pdf

[5] Kiss G. - Boldog V. (szerzők) Demeter E. (szerk.) (2020): Statisztikai jelentések - Dísznövénytermesztés és gyógynövényfelvásárlás 2019.év. NAIK Agrárgazdasági Kutatóintézet pp.18.

http://repo.aki.gov.hu/3592/1/Disznovenytermesztes_gyogynovenyfelvasarlas_2019.pdf 